\title{
Bioturbation behaviour of the spatangoid urchin Abatus ingens in Antarctic marine sediments
}

\author{
Belinda A. W. Thompson ${ }^{1,2, *}$, Martin J. Riddle ${ }^{1}$ \\ ${ }^{1}$ Human Impacts Research Program, Australian Antarctic Division, Channel Highway, Kingston, Tasmania 7050, Australia \\ ${ }^{2}$ University of Tasmania, Sandy Bay, Tasmania 7004, Australia
}

\begin{abstract}
A series of in situ and aquarium experiments were conducted in the vicinity of the Bailey Peninsula area (Casey Station, East Antarctica) to investigate the bioturbation behaviour of the Antarctic spatangoid urchin Abatus ingens (Koehler 1928). Rates of sediment transport by A. ingens were estimated from measurements of locomotion rates, sediment reworking depth and feeding rates. A. ingens bioturbates and feeds on the surface sediment (top 1 to $2 \mathrm{~cm}$ ) by pushing diatom communities and sediment ahead and to the side of its track, thus increasing vertical and horizontal sediment transport. Over a $24 \mathrm{~h}$ period in situ, $A$. ingens spends prolonged periods of time stationary $(16.7 \mathrm{~h})$ and only short periods of time in locomotion $(7.3 \mathrm{~h})$. In the aquarium, however, A. ingens was observed to spend half of the time moving and the other half stationary. Locomotion rate measured in the aquarium was faster $\left(1.95 \mathrm{~cm} \mathrm{~h}^{-1}[1.20 \mathrm{SD}]\right)$ than in situ $\left(0.30 \mathrm{~cm} \mathrm{~h}^{-1}\right.$ [0.27 SD]). In addition, $A$. ingens moves significantly faster during light hours than periods of darkness in situ. An ingestion rate of 0.02 to $0.06 \mathrm{~g} \mathrm{~h}^{-1}$ of dry sediment was measured for $A$. ingens, with a gut sediment passage time of 72 to $97 \mathrm{~h}$. A. ingens reworks $2.76 \mathrm{~cm}^{3} \mathrm{~h}^{-1}$ (2.52 SD) in situ; however, this calculation (based on forward movement only) may be an underestimate because $A$. ingens still reworks the sediment (via rocking and rotating on the spot) when it is not moving forwards. It is concluded that $A$. ingens is a significant contributor to the reworking of sediments in the Antarctic benthic environment.
\end{abstract}

KEY WORDS: Abatus ingens $\cdot$ Bioturbation $\cdot$ Antarctica $\cdot$ Spatangoid urchins

Resale or republication not permitted without written consent of the publisher

\section{INTRODUCTION}

Spatangoid urchins bioturbate the sediment via nonselective deposit-feeding, burrowing beneath the sediment surface and during locomotion (Chesher 1969, De Ridder et al. 1984, Hollertz \& Duchene 2001). Their bioturbation is important in maintaining infaunal and microbial community diversity (Widdicombe et al. 2000), the exchange of solutes across the sedimentwater interface (Bird et al. 1999), the breakdown of sediment-bound contaminants (Thompson et al. unpubl. data), nutrient and particle mixing (Yingst \& Rhoads 1980, Sandnes et al. 2000), and increasing the depth to which oxygen penetrates (Osinga et al. 1995, Widdicombe \& Austen 1998).

Some spatangoid species (e.g. Echinocardium cordatum and Brissopsis lyrifera) burrow 15 to $20 \mathrm{~cm}$ below the sediment surface and have a funnel, connecting the burrow to the sediment surface, which is used for respiration and feeding (De Ridder et al. 1984, De Ridder \& Jangoux 1985, Hollertz \& Duchene 2001, Hollertz 2002). Sediment particles may be trapped in the funnel passively or actively by the funnel-building tube feet, and then are transferred to the ventrallylocated mouth by specialised tube feet (phyllopods). Spatangoids are, therefore, able to feed on both surface and sub-surface sediment, ingesting organic detritus, bacteria and infaunal organisms (Mortensen 1927, Yingst \& Rhoads 1980). Deeper sediments with low organic content are thought to play an important mechanical role in the digestive processes of spatangoid urchins (De Ridder et al. 1985).

Spatangoid spines are used for burial and locomotion (Smith 1980, Kanazawa 1992). During burial, 
metachronal waves transport sediment upwards, i.e. from below the oral face to the aboral face (Hollertz \& Duchene 2001), and consequently move deep sediment towards the surface.

The spatangoid Abatus ingens (Koehler 1926) is endemic (native) to Antarctica. It mostly occurs in water depths of between 2 and $761 \mathrm{~m}$, and does not burrow beneath the sediment surface (David et al. 2000). The average length of an adult is 60 to $70 \mathrm{~mm}$ (David et al. 2000). Like many Antarctic benthic species, A. ingens is a brooding species with as many as 149 juveniles recorded from the pouches of a single female (Lockhart et al. 1994, Poulin et al. 2002).

Casey Station is an Australian research station located on the Bailey Peninsula in East Antarctica. The local benthic environment has low sediment resuspension rates because, for much of the year, it is protected from wave action by sea-ice and there is little tidal movement compared to many temperate and tropical regions; thus, bioturbation is possibly the main pathway for sediment reworking. In several shallow (<35 m) bays in the Bailey Peninsula area, spatangoids such as Abatus ingens, $A$. nimrodi and $A$. shackletoni are common, and it is hypothesised that they are important contributors to sediment reworking because of their size and abundance.

This study aims to characterize the bioturbation behaviour of the burrowing spatangoid Abatus ingens through field and aquarium studies. Sediment transport, locomotion rates, sediment reworking depth and feeding rates were measured in order to calculate sediment reworking rates and to quantify the role of A. ingens in some Antarctic sediments.

\section{MATERIALS AND METHODS}

Stations and sampling. Casey Station (66.28 $\mathrm{S}$, $110.53^{\circ} \mathrm{E}$ ) is located on the Bailey Peninsula adjacent to an area of low rocky islands known as the Windmill Islands (Fig. 1). On the southern side of the Bailey Peninsula is O'Brien Bay, which is $3 \mathrm{~km} \times 2 \mathrm{~km}$ and up to $80 \mathrm{~m}$ deep. The underwater topography of O'Brien Bay is gently sloping with large expanses of sediment 5 to $20 \mathrm{~cm}$ deep (85\%), with boulder outcrops $(15 \%)$ and no macroalgae. The sediment floor is covered with a film of diatoms and supports various mobile macro-invertebrates (e.g. Abatus sp., asteroids, nemerteans).

Sediment was collected from O'Brien Bay (OB2; Fig. 1) in November 2002 by divers using 151 polyethylene buckets at $\sim 15 \mathrm{~m}$ depth. Sediment was frozen $\left(-20^{\circ} \mathrm{C}\right)$ for $24 \mathrm{~h}$ to defaunate the sediment, then thawed and sieved with a $500 \mu \mathrm{m}$ sieve and left to settle. Approximately 5\% (wet volume) of the sedi-

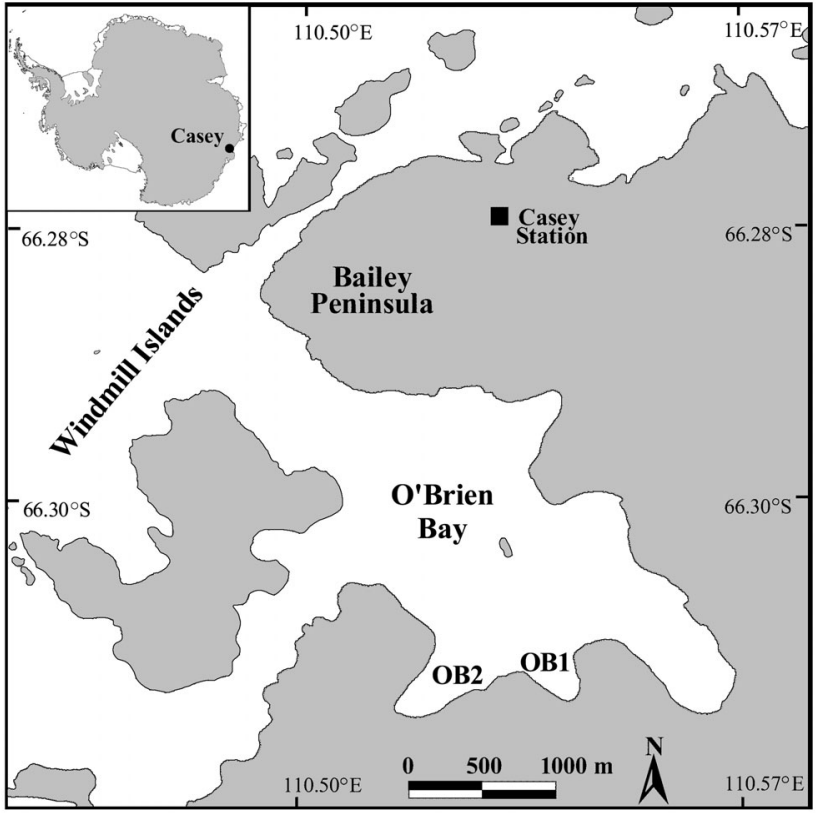

Fig. 1. Locations of the in situ experiments in the Casey area

ment collected was retained on the $500 \mu \mathrm{m}$ sieve and sediment $<500 \mu \mathrm{m}$ was used in all the experiments.

Specimens of Abatus ingens were collected from O'Brien Bay (OB1; Fig. 1) in December 2002 by divers at $\sim 15 \mathrm{~m}$ depth. To reduce stress to the spatangoids caused by transportation, each specimen was placed in a separate 11 container underwater by divers and transported in the containers to the aquarium at Casey Station. The animals acclimatised in aquaria on sieved sediments $(\sim 5 \mathrm{~cm}$ depth) for $1 \mathrm{wk}$ before the experiments. Sea water in the aquarium was aerated, and maintained at $-0.5^{\circ} \mathrm{C}( \pm 0.2)$ and $34.0 \mathrm{psu}( \pm 0.5)$ for the duration of all experiments.

Logistical constraints prevented divers from collecting urchin specimens from the same location as the sediments; however, both sampling stations within O'Brien Bay (OB1 and OB2) had similar underwater topography, faunal composition and sediment characteristics.

Bioturbation behaviour observations. Fine-scale movements of Abatus ingens were recorded (2 $\mathrm{s}$ of recording every $30 \mathrm{~s}$ for $4 \mathrm{~h}$ ) on a time-lapse digital video camera (Sony Mini DV). Locomotion and bioturbation behaviour, including metachronal spine activity, rotational movement, feeding and rocking/bulldozing behaviour, was observed on 12 urchins separately (width $=5.2 \mathrm{~cm}[0.8 \mathrm{SD}]$, height $=3.4 \mathrm{~cm}[0.4 \mathrm{SD}]$, length $=5.9 \mathrm{~cm}[0.8 \mathrm{SD}])$. The aquarium set-up and conditions were exactly as described below in the 'Rate of locomotion' experiment.

Sediment displacement. To study how Abatus ingens bioturbates the sediment, 2 different coloured 
(pink and green) sediment tracers (125 to $425 \mu \mathrm{m}$ luminophores sourced from The Institute of Geosciences, University of Kiel) were used. Luminophores are sand-grains treated so they fluoresce under UV light.

Based on the method of Gilbert et. al. (1996), frozen sediment layers containing $30 \mathrm{~g}$ luminophores $\mathrm{l}^{-1}$ of wet sediment were laid on top of each other in trays lined with $300 \mu \mathrm{m}$ mesh. The bottom layer contained no luminophores ( $8.0 \mathrm{~cm}$ thick), the next layer up contained green luminophores ( $0.5 \mathrm{~cm}$ thick), followed by a layer with no luminophores (1.0 cm thick), and a layer with pink luminophores was laid on the surface $(0.5 \mathrm{~cm}$ thick $)$.

Trays were deployed in O'Brien Bay (OB1; Fig. 1), while the sediment was frozen. Divers placed 8 trays on the sea bed (13.5 $\mathrm{m}$ deep), arranged haphazardly in an area roughly $6 \mathrm{~m} \times 6 \mathrm{~m}$ in December 2002. Once the sediment was partially thawed, divers placed Abatus ingens $(\mathrm{n}=2$ per tray; width $=5.0 \mathrm{~cm}[0.6 \mathrm{SD}]$, length = $5.7 \mathrm{~cm}[0.6 \mathrm{SD}]$, height $=3.2 \mathrm{~cm}[0.4 \mathrm{SD}]$ ) on the sediment surface of 4 selected trays. No $A$. ingens were added to the remaining 4 trays. Densities of $A$. ingens in the trays were similar to those in adjacent ambient communities.

Nine weeks after deployment, divers placed 4 corertubes (21 mm internal diameter) per tray in the tracks behind the urchins and in the control sediment. Trays were then lifted to the surface where the sediment cores were retrieved immediately and sectioned into $1.0 \mathrm{~cm}$ intervals. The sediment samples were subsequently oven-dried $\left(60^{\circ} \mathrm{C}\right)$ for $24 \mathrm{~h}$ and then broken up with mortar and pestle. Sub-samples $(1.0 \mathrm{~g})$ were spread out under UV light, where the green and pink luminophores were counted.

Urchins from the trays were collected, and the numbers of coloured luminophores in their guts were counted to estimate the depth to which Abatus ingens feeds.

Rate of locomotion. In situ: A time-lapse digital video camera (Sony Mini DV) was connected to a small computer and placed into an underwater housing. The computer controlled operation of the camera and two $12 \mathrm{~V}$ lights (MR11 HID dive lights fitted with Solarc lamps) powered by two $12 \mathrm{~V}$ batteries. The lights, housing and batteries were all on a frame supported by 4 legs. The computer was programmed to turn on the 2 light sources for $5 \mathrm{~s}$ every $20 \mathrm{~min}$ during which the camera recorded $1 \mathrm{~s}$ of footage. The lights (and camera) were turned off between filming to reduce bias caused by permanent illumination.

Divers deployed this camera system in O'Brien Bay (OB1; Fig. 1) 4 times between November 2002 and January 2003. Due to the cold water temperature $\left(-1.7^{\circ} \mathrm{C}\right)$, battery life was on average only $4 \mathrm{~d}$; thus, the urchin's position was recorded in situ every 20 min over $96 \mathrm{~h}$. A square quadrat $\left(0.25 \mathrm{~m}^{2}\right)$ was initially placed in the field of view $(90 \mathrm{~cm} \times 70 \mathrm{~cm})$ to provide calibration of the videoed area.

Still frames of the urchin's position were captured from the digital video using Media Studio Pro v.5 every 8 s (i.e. $2.6 \mathrm{~h}$ real time). Shorter time increments were used if the distance travelled between the $8 \mathrm{~s}$ increments was greater than $10 \mathrm{~cm}$. The images were analysed using Adobe Photoshop Elements v2.0 software and the urchin's position was plotted at each time increment. The distance covered over the duration of the experiment was measured and the average rate of locomotion per hour calculated $(\mathrm{n}=12)$. In addition, the distance moved during light and dark periods was calculated to determine the effect of light on locomotion rates. Since specimens of Abatus ingens were not caged in, some individuals passed through the camera frame, while others permanently remained in the frame. For $A$. ingens that moved into or out of the frame, the distance moved by the urchin was averaged over the number of hours they remained in the camera frame.

Aquaria: A time-lapse digital video camera (Sony Mini DV) was used to record (1 s every $5 \mathrm{~min}$ ) the position of 6 urchins in 1 round aquarium $(85.5 \mathrm{~cm}$ diameter) over $96 \mathrm{~h}$, from which locomotion rates were calculated. The camera was mounted above the aquaria. This experiment was consecutively repeated twice with different Abatus ingens specimens ( $\mathrm{n}=12$ urchins) and the same urchins used in the 'Bioturbation behaviour observations' experiment were used here. The tank was illuminated with a $60 \mathrm{~W}$ pearl light for the duration of the experiment and was shaded to exclude reflective light on the water surface. The sieved sediments were very fine $(41.1 \%$ sand, $57.0 \%$ silt and $1.7 \%$ clay) and to maintain good water clarity in the aquaria, sediments $(\sim 10 \mathrm{~cm}$ depth) were added to the aquaria tub and frozen before water $(\sim 40 \mathrm{~cm}$ depth) was gently added. Once the sediments thawed, the urchins were added and allowed to acclimatise to the new aquaria for $10 \mathrm{~h}$ before the experiment commenced.

A $5 \mathrm{~cm} \times 5 \mathrm{~cm}$ grid was placed at the bottom of the tank prior to the start of each experiment to provide calibration of the videoed area. Still frames of the urchin's position were captured from the digital video every $30 \mathrm{~s}$ (i.e. $2.5 \mathrm{~h}$ real time), and the images and locomotion rates were analysed as for in situ footage described above.

Ingestion rates. Luminophores (125 to $425 \mu \mathrm{m})$ were added and thoroughly mixed in with previously collected and sieved sediment (30 g luminophores $\mathrm{l}^{-1}$ wet sediment). The sediment and luminophore mix were frozen in plastic aquaria tubs $(27 \mathrm{~cm} \times 32 \mathrm{~cm})$. The tubs 
were placed in chilled water aquaria baths and seawater was decanted onto the frozen sediment. Sediment was $4.0 \mathrm{~cm}$ deep with $10.0 \mathrm{~cm}$ of over-lying water.

Once the sediment had thawed, the urchins ( $\mathrm{n}=2$ per aquaria tub) were placed onto the sediment traced with luminophores and left to feed. The urchins used were not starved before their use in this experiment. Three Abatus ingens were removed from selected aquaria tubs $1,5,15,24,45,72$ and $97 \mathrm{~h}$ after commencement. All sampled urchins were immediately frozen at $-20^{\circ} \mathrm{C}$ to stop gut movement. The urchins were subsequently thawed and their guts dissected into $1.0 \mathrm{~cm}$ sections.

The $1.0 \mathrm{~cm}$ gut sections were oven dried at $60^{\circ} \mathrm{C}$ for $24 \mathrm{~h}$ and the dry mass recorded. Each $1.0 \mathrm{~cm}$ gut section was analysed for the presence or absence of luminophores. The presence of luminophores in a gut section indicated that the sediment in that section had been ingested during the experiment. The sediment ingestion rate for each individual $(\mathrm{n}=21)$ was calculated by adding the dry weights of sediment in all gut sections containing luminophores and dividing by the duration of the experiment. Abatus ingens used in this study ranged from 4.1 to $5.6 \mathrm{~cm}$ in length, 3.2 to $4.9 \mathrm{~cm}$ in width and 2.0 to $2.9 \mathrm{~cm}$ in height. To account for differences in $A$. ingens gut length, the percentage of total gut weight ingested since the start of the experiment was calculated by dividing the weight of sediment ingested by the total gut content weight. The gut passage time was calculated from the time needed for luminophores to reach the last section of the gut.

Sediment particles from all spatangoid gut samples and from aquaria sediments were analysed for grain size using a Malvern $2600 \mathrm{C}$ laser particle size analyser. Particles were separated into 3 size categories: sand $(>63 \mu \mathrm{m})$, silt $(2-63 \mu \mathrm{m})$ and clay $(<2 \mu \mathrm{m})$.

Bioturbation rates. The average surface area of sediment reworked for each Abatus ingens per hour was calculated by multiplying the average distance $(\mathrm{cm})$ covered by a spatangoid in $1 \mathrm{~h}(D)$ by the average urchin width $\left(A_{\mathrm{w} i} \mathrm{~cm}\right)$. To calculate the volume of sediment reworked, the area reworked was multiplied by the estimated depth to which the urchin burrowed during locomotion $\left(S_{\mathrm{d} i} \mathrm{~cm}\right)$. The volume of sediment ingested was not added to the reworked volume because observations indicated that ingested sediment was taken from the area in front of the urchin, which would otherwise have been displaced as A. ingens moved forwards.

Sediment surface area reworked per hour $=D \times A_{\mathrm{w}}$ Sediment volume reworked per hour $=D \times A_{\mathrm{w}} \times S_{\mathrm{d}}$

Statistical analysis. Data from the sediment displacement study was analysed by a 2 -factor analysis of vari- ance (ANOVA) design, using the statistical package GMAV (Underwood \& Chapman 1998). The treatment factor, presence of Abatus ingens, was fixed and the second factor, tray replicates, was random and nested within the treatment factor. The number of each colour of luminophore from each $1.0 \mathrm{~cm}$ section of replicate cores $(\mathrm{n}=4)$ taken from trays with and without bioturbation, were tested against each other. The effect of location on the rate of locomotion was tested using a 1-factor ANOVA design with 2 fixed levels (aquaria and in situ; $\mathrm{n}=12$ ). Differences in locomotion rates during day and night hours were tested against each other using a 1 -factor ANOVA with 2 fixed levels (day or night; $\mathrm{n}=12$ ). The effect of duration of feeding was tested using a 1-factor ANOVA design with 7 fixed levels (hours of feeding; $\mathrm{n}=3$ ). To determine whether $A$. ingens selectively ingests particles of a particular size, differences in grain-size in the gut and in the aquarium sediments were tested using a 1-factor ANOVA with 2 fixed levels (location $; \mathrm{n}=8$ ). Similarly, to estimate $A$. ingens feeding depth, differences in coloured luminophores within the gut were analysed using a 1 -factor ANOVA with 2 fixed levels (colour; $\mathrm{n}=8$ ).

Homogeneity of variances were analysed using Cochran's $C$-test and, if heterogenous, were transformed (Snedecor \& Cochran 1989). A significance level of 0.05 was used. When a treatment factor was significant, the differences between levels were determined using the Student-Newman-Keuls test (SNK test).

\section{RESULTS}

\section{Observations of bioturbation behaviour}

Typically, Abatus ingens burrowed into the sediment to a depth of $2.0 \mathrm{~cm}$, so that only the basal part of the test was buried. At no time was it observed that $A$. ingens completely burrowed beneath the sediment surface.

Analysis of the time-lapse video from in situ and aquarium studies showed Abatus ingens moving through the sediment with a slight rocking motion $\left(<5^{\circ}\right.$ on either side of the axis), pushing surface sediment off to the sides and exposing the underlying sediment to the water column (Fig. 2).

When stationary, Abatus ingens rocks and rotates on its axis; these movements cause sediment to be moved from below the test to the dorsal side and also cause the urchin to sink into the sediment to a depth of $2.0 \mathrm{~cm}$ therefore, sediment is still being turned over when $A$. ingens is stationary and bioturbation rates are greater than those based on forward movement only.

The in situ time-lapse camera recorded a spatangoid urchin righting itself in just under $4 \mathrm{~h}$, after being tipped upside down by a passing fish. 


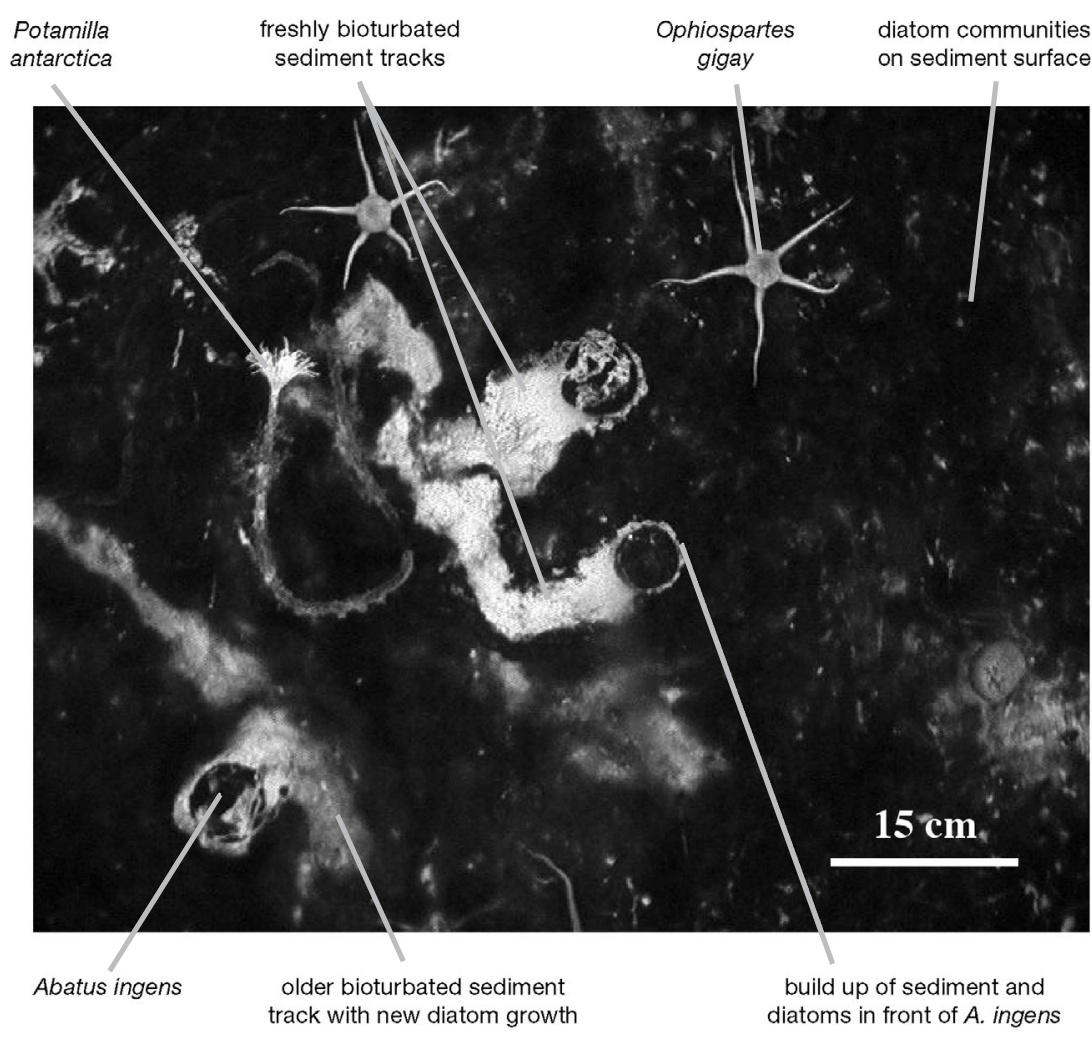

Fig. 2. Still frame from the underwater time-lapse video the pink luminophores), thus exposing the deeper layers containing the green luminophores. The absence of luminophores below $4.0 \mathrm{~cm}$ suggests that A. ingens does not rework sediments to this depth (Fig. 3a,b).

There were significantly more $(F=$ 14.37; $\mathrm{p}<0.05 ; \mathrm{n}=8$ ) pink than green luminophores in the guts of urchins sampled from the trays; indicating that Abatus ingens feeds predominantly on the surface 0 to $2 \mathrm{~cm}$ layer. Even though there were more pink than green luminophores in the top $2 \mathrm{~cm}$ of unbioturbated sediments (Fig. 3a), the ratio of green to pink luminophores in sediments from $A$. ingens gut (1:10) was greater than the ratio in the nonbioturbated sediments (1:3). This demonstrates that the greater numbers of pink luminophores in $A$. ingens gut are not an artefact created by the predominance of pink over green luminophores in the sediments.

\section{Rate of locomotion}

\section{Sediment displacement}

In the absence of Abatus ingens bioturbation, the pink and green luminophore layering remained largely separated (Fig. 3a), while the luminophore layering in the trays with $A$. ingens bioturbation was clearly mixed (Fig. 3b). In trays with $A$. ingens bioturbation, there were significantly fewer pink luminophores in the 0 to $1 \mathrm{~cm}$ layer and significantly more green luminophores than in the undisturbed rays (Table 1 ). This is due to $A$. ingens pushing aside the top 0 to $1 \mathrm{~cm}$ of sediment (containing

Table 1. ANOVA summary results from the sediment displacement experiment comparing luminophores (of the same colour and from the same $1.0 \mathrm{~cm}$ section) between trays with and without Abatus ingens bioturbation $(\mathrm{n}=32$; $\mathrm{df}=1)$. Significant results are in bold $(\mathrm{p}<0.05)$

\begin{tabular}{|lrrrr|}
\hline \multirow{2}{*}{ Sample } & \multicolumn{2}{c}{ Pink luminophores } & \multicolumn{2}{c|}{ Green luminophores } \\
& F-value & p value & F-value & p value \\
\hline $0-1$ & 30.40 & $\mathbf{0 . 0 0 2}$ & 33.50 & $\mathbf{0 . 0 0 1}$ \\
$1-2$ & 0.17 & 0.700 & 0.35 & 0.575 \\
$2-3$ & 0.09 & 0.775 & 0.19 & 0.676 \\
$3-4$ & 3.83 & 0.098 & 10.24 & $\mathbf{0 . 0 1 9}$ \\
$4-5$ & 1.45 & 0.274 & 1.45 & 0.274 \\
$>5$ & 1.45 & 0.274 & 1.45 & 0.274 \\
\hline
\end{tabular}

Abatus ingens moved significantly $(F=21.54 ; \mathrm{df}=1$; $\mathrm{p}=0.001 ; \mathrm{n}=24)$ faster in the aquarium $\left(1.95 \mathrm{~cm} \mathrm{~h}^{-1}\right.$ [1.20 SD]) than in situ $\left(0.30 \mathrm{~cm} \mathrm{~h}^{-1}[0.27 \mathrm{SD}]\right)$. The fastest rates (averaged over $96 \mathrm{~h}$ ) recorded were 3.27 and $1.05 \mathrm{~cm} \mathrm{~h}^{-1}$ in the aquarium and in situ respectively; while the slowest rates were $0.10 \mathrm{~cm} \mathrm{~h}^{-1}$ (aquarium) and $0.05 \mathrm{~cm} \mathrm{~h}^{-1}$ (in situ). Over a $24 \mathrm{~h}$ period in situ, A. ingens spent prolonged periods of time stationary $(16.7 \mathrm{~h})$ and only short periods of time in locomotion $(7.3 \mathrm{~h})$. In the aquarium, however, $A$. ingens spent half of the time in locomotion and the other half stationary. In addition, $A$. ingens moved significantly ( $F=$ 5.57; df $=1 ; \mathrm{p}<0.05 ; \mathrm{n}=12$ ) faster during light hours $\left(0.61 \mathrm{~cm} \mathrm{~h}^{-1}[1.10 \mathrm{SD}]\right)$ than during periods of darkness in situ $\left(0.09 \mathrm{~cm} \mathrm{~h}^{-1}[0.14 \mathrm{SD}]\right)$.

\section{Sediment ingestion}

Sediment ingestion rates based on the rate of progression of luminophores through the gut, after at least $5 \mathrm{~h}$ after commencement of the experiment, were 0.02 to $0.06 \mathrm{~g} \mathrm{~h}^{-1}$ (dry sediment) (Table 2). SNK tests demonstrated no significant variability between the rates of ingestion for the period 5 to $97 \mathrm{~h}$ after commencement of the experiment. The mean gut content weight was $2.73 \mathrm{~g}(0.93 \mathrm{SD})$ (dry sediment; $\mathrm{n}=21$ ) and 

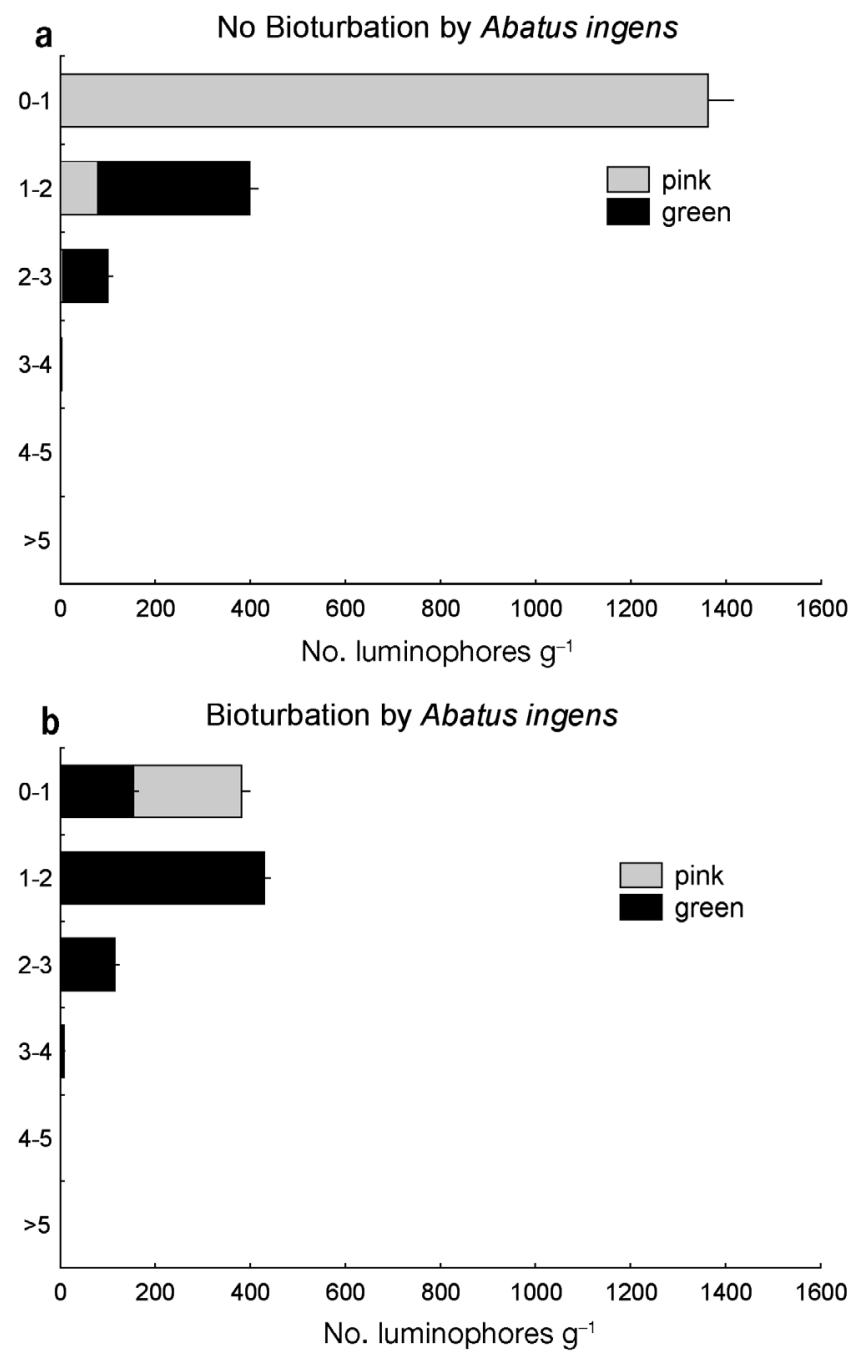

Fig. 3. Summary results from the in situ Abatus ingens sediment displacement experiment. Bars represent the mean values (with standard deviations) of pink and green luminophores (per gram of dry weight sediment) per $1.0 \mathrm{~cm}$ section from (a) trays with no bioturbation and (b) trays with bioturbation; $\mathrm{n}=16$ $\sim 1$ to $3 \%$ of Abatus ingens gut content weight was ingested per hour (Table 2).

The apparent sediment ingestion rate calculated for $1 \mathrm{~h}$ after commencement of the experiment $(0.21 \mathrm{~g}$ [0.18 SD] dry sediment $\mathrm{h}^{-1}$ ) was significantly higher $(F=7.94 ; \mathrm{df}=6 ; \mathrm{p}=0.007 ; \mathrm{n}=21)$ than for any other period. This is an artefact created by mixing recently ingested sediment in the first gut loop (between the oesophagus and the caecum). This mixing moves some of the recently ingested sediment (represented by the presence of luminophores) further along the gut than would occur by sediment ingestion alone. Mixing in the foregut was inferred because the concentration of luminophores in the fore gut after $1 \mathrm{~h}$ was very much lower (37 luminophores $\mathrm{g}^{-1}$ dry sediment) than in subsequent time periods (535 luminophores $\mathrm{g}^{-1}$ dry sediment after $97 \mathrm{~h}$ ). Luminophore concentrations in the other gut sections did not increase over time. For this reason, sediment ingestion rates reported here for Abatus ingens do not include the first hour of feeding.

The sediment gut passage time for Abatus ingens was 72 to $97 \mathrm{~h}$, with only 1 individual not completing the process after $97 \mathrm{~h}$ (Table 2). There was no significant difference between sediment particle sizes in $A$. ingens gut and the surrounding sediments (Table 3 ), indicating that $A$. ingens does not select for particular particle sizes. Sediments used in this study had $60 \%$ water content and a wet sediment density of $1.482 \mathrm{~g} \mathrm{~cm}^{-3}$. From these values, the mean dry sediment ingestion rate per hour of $0.043 \mathrm{~g}$ equates to a wet sediment volume of $0.046 \mathrm{~cm}^{3}$.

\section{Bioturbation rates}

In the aquarium, the average area of sediment reworked per individual was $8.96 \mathrm{~cm}^{2} \mathrm{~h}^{-1}$ (5.52 SD) and the volume reworked was $17.93 \mathrm{~cm}^{3} \mathrm{~h}^{-1}$ (11.03 SD); based on the average Abatus ingens width of $4.6 \mathrm{~cm}$

Table 2. Abatus ingens. Sediment ingestion rates (dry mass; with standard deviations) measured using sediment labelled with coloured luminophores

\begin{tabular}{|c|c|c|c|c|c|}
\hline $\begin{array}{l}\text { Hours } \\
\text { feeding } \\
\text { (a) }\end{array}$ & $\begin{array}{l}\text { Total sediment } \\
\text { ingested (g) } \\
\text { (b) }\end{array}$ & $\begin{array}{c}\text { Sediment } \\
\text { ingested }(\mathrm{g}) \mathrm{h}^{-1} \\
(\mathrm{~b} / \mathrm{a})\end{array}$ & $\begin{array}{l}\text { Total gut } \\
\text { weight (g) } \\
\text { (c) }\end{array}$ & $\begin{array}{c}\% \text { of total gut } \\
\text { weight ingested } \\
(\mathrm{b} / \mathrm{c}) \times 100\end{array}$ & $\begin{array}{c}\% \text { of total gut weight } \\
\text { ingested } \mathrm{h}^{-1} \\
(\mathrm{~b} / \mathrm{c}) / \mathrm{a}\end{array}$ \\
\hline 1 & $0.21(0.18)^{\mathrm{a}}$ & $0.21(0.18)$ & $2.34(0.95)$ & $9.0(7.4)$ & $9.0(7.4)$ \\
\hline 5 & $0.31(0.07)$ & $0.06(0.01)$ & $2.36(1.15)$ & $13.1(10.6)$ & $2.6(2.1)$ \\
\hline 15 & $0.48(0.05)$ & $0.03(0.00)$ & $2.92(0.29)$ & $16.4(3.3)$ & $1.1(0.2)$ \\
\hline 24 & $1.13(0.13)$ & $0.05(0.01)$ & $2.76(0.98)$ & $40.9(17.4)$ & $1.7(0.7)$ \\
\hline 45 & $2.50(0.56)$ & $0.06(0.01)$ & $2.83(0.97)$ & $88.3(12.1)$ & $1.9(0.3)$ \\
\hline 72 & 3.03 (1.15) & $0.04(0.02)$ & 3.03 (1.15) & $100(0.0)$ & $1.4(0.0)$ \\
\hline 97 & $2.24(1.48)$ & $0.02(0.02)$ & $2.83(1.29)$ & $79.1(34.8)$ & $0.8(0.4)$ \\
\hline
\end{tabular}


Table 3. Particle size distribution of the aquaria and Abatus ingens gut sediments; with 1-factor ANOVA results comparing the particle size fractions between $A$. ingens gut and surrounding aquaria sediments; $\mathrm{n}=8$

\begin{tabular}{lcccccc|}
\hline Particle size & $\begin{array}{c}\text { Surrounding } \\
\text { aquaria } \\
\text { sediment }(\%)\end{array}$ & $\begin{array}{c}\text { Gut } \\
\text { contents } \\
(\%)\end{array}$ & & F-value & df & p-value \\
\hline $\begin{array}{l}\text { Sandy fraction } \\
>63 \mu \mathrm{m}\end{array}$ & 45.8 & 47.6 & 1.02 & 1 & 0.35 \\
$\begin{array}{l}\text { Silt fraction } \\
2-63 \mu \mathrm{m}\end{array}$ & 52.8 & 51.0 & 1.17 & 1 & 0.32 \\
$\begin{array}{l}\text { Clay fraction } \\
<2 \mu \mathrm{m}\end{array}$ & 1.4 & 1.4 & 1.00 & 1 & 0.36 \\
& & & & & & \\
\hline
\end{tabular}

(0.79 $\mathrm{SD} ; \mathrm{n}=51)$. In situ, however, the average area reworked was $1.38 \mathrm{~cm}^{2} \mathrm{~h}^{-1}(1.26 \mathrm{SD})$, while the volume reworked was $2.76 \mathrm{~cm}^{3} \mathrm{~h}^{-1}(2.52 \mathrm{SD})$.

Based on in situ dark and light locomotion rates, each Abatus ingens will, on average, rework $0.83 \mathrm{~cm}^{3} \mathrm{~h}^{-1}$ $(1.30 \mathrm{SD})$ of sediment during dark periods and $5.61 \mathrm{~cm}^{3}$ $\mathrm{h}^{-1}(10.31 \mathrm{SD})$ of sediment during light periods.

\section{DISCUSSION}

Abatus ingens pushes aside the sediment surface during forward locomotion, resulting in the displacement of sediment and surface living diatom communities ahead and to the side of the track. As the top 1 to $2 \mathrm{~cm}$ of sediment is pushed aside, the surface oxygenated sediments (to the side of the track) become buried and the underlying sediments (within the track) are brought to the surface and exposed to the water column. Upward movement of sediment was confirmed by the presence of luminophores on the dorsal side of the test after $1 \mathrm{~h}$ of feeding during the ingestion experiment; thus, $A$. ingens increases both vertical and horizontal sediment transport. Sediment below $4.0 \mathrm{~cm}$ remains undisturbed during forward locomotion; however, these deeper sediments may be displaced by rocking and rotating movements that are associated with burial during the 'stationary periods'.

Temperate and tropical spatangoid urchins (e.g. Meoma ventricosa, Brissopsis alta and Echinocardium cordatum) move 7 to 27 times faster than Abatus ingens (Chesher 1968, 1969, Buchanan 1966). Within individual species, low temperatures are known to reduce the locomotion rates of spatangoid urchins. For example, Schizaster canaliferus reduced its locomotion rate from 0.5 to $0.2 \mathrm{~cm} \mathrm{~h}^{-1}$ when the water temperature decreased from 20 to $12^{\circ} \mathrm{C}$ (Schinner 1993). It has been suggested that low ambient temperatures $\left(-1.7^{\circ} \mathrm{C}\right)$ may force Antarctic benthic organisms to exhibit generally lower locomotor activity and growth rates in order to conserve metabolic energy (Brey \& Clarke 1993, Arntz et al. 1994, Knox 1994). This is consistent with our observations that locomotion rates of $A$. ingens are considerably lower than spatangoids from warmer waters.

The documented effect of light on spatangoid locomotion rates varies between species. For example, Plagiobrissus grandis (Hammond 1982) will increase its activity during the day, while Meoma ventricosa (Chesher 1969, Hammond 1982) is more active at night. During the winter months in Antarctica, there are days without any sunlight, while in the middle of summer there can be $24 \mathrm{~h}$ of light. Abatus ingens was more active during daylight hours at a time of year when there is diurnal variation of irradiance. Although we demonstrate a correlation between irradiance intensity and activity of $A$. ingens, our experiments were not designed to test whether there is a causal relationship; however, if activity is linked to irradiance intensity, sediment reworking rates may be higher over the summer months than during winter. Studies over the Antarctic winter months would be required to determine whether locomotion rates are consistently slower during the extended period of winter darkness.

Other factors such as food availability also vary from summer to winter (Arntz et al. 1994), possibly influencing Abatus ingens locomotion speed. Certain spatangoids are known to move faster in areas of low food availability (Hammond 1982) and will regulate their feeding depth or location depending on food availability and quantity (Hollertz 2002). Like most spatangoids, A. ingens is a non-selective deposit feeder with respect to sediment grain-size and feeds on organic rich sediments in the Bailey Peninsula area (0.6 \pm $0.03 \%$ TOC [w/w dry mass; $\mathrm{n}=21$ ]). Brissopsis lyrifera typically lives in an organic rich environment and has ingestion rates $\left(0.02\right.$ to $\left.0.08 \mathrm{~g} \mathrm{~h}^{-1}\right)$ and gut passage times $\left(75 \mathrm{~h}\right.$ at $\left.7^{\circ} \mathrm{C}\right)$ that are similar to $A$. ingens (Hollertz \& Duchene 2001). In contrast, Echinocardium cordatum lives in nutritionally poor sandy habitats and has an ingestion rate 6 to 19 times higher than $A$. ingens; and when starved, E. cordatum will ingest more surface sediment than normally fed individuals (De Ridder \& Jangoux 1985). This suggests that spatangoids may ingest more sediment and will move faster when the organic content is low in order to obtain the required nutrients. However, experimental studies have shown that $B$. lyrifera increases ingestion rates when placed in microalga-enriched sediments (Hollertz 2002).

The volume of sediment reworked in situ by Abatus ingens is 75 times greater than the volume of sediment ingested. Similarly, Hollertz \& Duchene (2001) reported that Brissopsis lyrifera reworks 60 - to 150-fold more sediment by moving through the sediment, than 
from sediment ingested; however, it is suggested that the small amount of sediment ingested is still important in the reworking of sediments because of biochemical modification of sediments within the gut.

Abatus ingens moved 6.5 times faster in the aquarium than in situ. This may be attributed to differences in environmental conditions between the aquaria and in situ; such as light intensity (Chesher 1969, Hammond 1982), dissolved oxygen levels (Nichols 1959, Chesher 1969), sediment characteristics (Buchanan 1966) and food availability (Hammond 1982). Only a few locomotion rates have been calculated from in situ measurements (Chesher 1969, current study), while the majority are calculated from aquaria studies (Buchanan 1966, Schinner 1993, Hollertz \& Duchene 2001). Unless aquaria conditions can replicate the spatangoids habitat and environmental conditions exactly (which seems highly unlikely), locomotion rates calculated from aquaria studies must be interpreted with caution. This caution also holds true for ingestion rates calculated from aquaria studies, as spatangoids may increase or decrease their 'normal' ingestion rate depending on aquaria conditions.

In situ bioturbation rates of Abatus ingens are similar to the range of rates reported for Brissopsis lyrifera (3.5 to $4.7 \mathrm{~cm}^{3}$ sediment $\mathrm{h}^{-1}$; Hollertz \& Duchene 2001), but are 2 orders of magnitude less than has been reported for Meoma ventricosa $\left(330 \mathrm{~cm}^{3} \mathrm{~h}^{-1}\right.$; Chesher 1969). The estimated volume of sediment reworked was calculated by multiplying the forward displacement by the average test width and burial depth. These values, therefore, represent a minimum volume reworked, as they do not include sediment turned over as a result of burrowing and rocking, or rotating on axis. Hollertz \& Duchene (2001) found similar results and reported a 4fold underestimate of sediment reworked by B. lyrifera when calculated on forward displacement only. The bioturbation rates in this study, which are based on forward locomotion, are therefore underestimated.

Abatus spp. occur in densities of 1.2 to $11.25 \mathrm{~m}^{-2}$ in sediments surrounding the Bailey Peninsula area (unpubl. data). Although Abatus is not numerically dominant in the nearshore benthic infaunal communities (Stark 2001), it is one of the largest and most obvious disturbers of surface sediments. Other motile macrofauna such as nemerteans and asteroids are also present, but they do not disturb surface sediments to the extent that Abatus spp. do. Based on our in situ measurements of bioturbation rates (locomotion rate $\times$ depth of sediment reworked $\times$ average $A$. ingens width) and the densities of Abatus spp. in the Casey region, we estimate minimum sediment turnover rates of 3.31 to $31.05 \mathrm{~cm}^{3} \mathrm{~h}^{-1} \mathrm{~m}^{2}$ (or 28916 to $271253 \mathrm{~cm}^{3} \mathrm{yr}^{-1}$ $\mathrm{m}^{2}$ ). This equates to the top $2 \mathrm{~cm}$ of sediment being reworked 2 to 17 times per year. To our knowledge, no studies investigating the bioturbation potential of other Antarctic benthic species have been reported.

Information on the bioturbation behaviour of Abatus ingens and other motile macrofauna will help in predictions of sediment turnover rates in Antarctic sediments and will contribute to a greater understanding of how benthic particles are mixed. This is important for interpreting sediment stratigraphies for applications such as the investigation of past biological communities (Cremer et al. 2003) or environmental conditions (Taylor \& McMinn 2001). It will also contribute to a better understanding of fundamental sediment processes such as nutrient mixing, oxygen penetration and the establishment of layers of different redox potential.

At Casey, and at some other Antarctic stations where anthropogenic contaminants have been introduced into the marine environment, information on bioturbation could contribute to decisions on how contamination is best managed. Bioturbation may accelerate mixing of contaminants into deeper sediment layers where they could become unavailable for biological uptake. Alternatively, they may be transported to the surface and dispersed. Bioturbation may also enhance natural in situ bioremediation of contaminants such as hydrocarbons by sediment micro-organisms by helping to maintain sediment oxygen levels. In situ experimental studies are currently underway in O'Brien Bay to determine the interactions between Abatus ingens bioturbation, infaunal community recruitment and the residence time of hydrocarbon contaminants in Antarctic sediments.

Acknowledgements. The authors wish to thank P. M. Goldsworthy for his advice and help with the experimental designs and monitoring of experiments; A. Tabor, T. Veness and A. Poole for their help in the design and construction of the in situ time-lapse camera; A. Lane for her help with the aquarium at Casey Station; P. M. Goldsworthy, L. Bright, J. S. Stark, A. Lane, J. Lawler and S. Lessels for diving support; and members of the Australian Antarctic Program (2002/2003) at Casey Station. This project is funded by a PhD scholarship from The University of Tasmania and the Australian Antarctic Division (ASAC No. 2201).

\section{LITERATURE CITED}

Arntz WE, Brey T, Gallardo VA (1994) Antarctic zoobenthos. Oceanogr Mar Biol Annu Rev 32:241-304

Bird FL, Ford PW, Hancock GJ (1999) Effect of burrowing macrobenthos on the flux of dissolved substances across the water-sediment interface. Mar Freshw Res 50:523-32

Brey T, Clarke A (1993) Population dynamics of marine benthic invertebrates in Antarctic and subantarctic environments: Are there unique adaptations? Antarct Sci 5(3): 523-266

Buchanan JB (1966) The biology of Echinocardium cordatum (Echinodermata: spatangoida) from different habitats. J Mar Biol Assoc UK 46:97-114 
Chesher RH (1968) The systematics of sympatric species in West Indian Spatangoids. University of Miami Press, Miami, FL

Chesher RH (1969) Contributions to the biology of Meoma ventricosa (Echinoidea: Spatangoida). Bull Mar Sci 19: $72-110$

Cremer H, Roberts D, McMinn A, Gore D, Melles M (2003) The Holocene diatom flora of marine bays in the Windmill Islands, East Antarctica. Bot Mar 46:82-106

David B, Chone T, De Ridder C, Festeau A (2000) Antarctic echinoids. An interactive database on CD-ROM, Version 1.0. Biogeosciences Publisher, University of Burgundy

De Ridder C, Jangoux M (1985) Origine des sèdiments ingèrès et durèe du transit digestif chez l'oursin spatangide, Echinocardium cordatum (Pennant) (Echinodermata). Ann Inst Oceanogr 61:51-58

De Ridder C, Jangoux M, Van Impe E (1984) Food selection and absorption efficiency in the spatangoid echinoid Echinocardium cordatum (Echinodermata). Proceedings of the Fifth International Echinoderm Conference, Galway, 24-29 September, p 245-251

De Ridder C, Janoux M, De Vos L (1985) Description and significance of a peculiar intradigestive symbiosis between bacteria and a deposit-feeding echinoid. J Exp Mar Biol Ecol 96:65-75

Gilbert F, Stora G, Betrand JC (1996) In situ bioturbation and hydrocarbon fate in an experimental contaminated Mediterranean coastal ecosystem. Chemosphere 33(8): 1449-1458

Hammond LS (1982) Analysis of grain-size selection by deposit-feeding holothurians and echinoids (Echinodermata) from a shallow reef lagoon, Discovery Bay, Jamaica. Mar Ecol Prog Ser 8:25-36

Hollertz K (2002) Feeding biology and carbon budget of the sediment-burrowing spatangoid urchin Brissopsis lyrifera (Echinoidea: Spatangoida). Mar Biol 140(5):959-969

Hollertz K, Duchene JC (2001) Burrowing behaviour and sediment reworking in the spatangoid urchin Brissopsis lyrifera Forbes (Spatangoida). Mar Biol 139:951-957

Kanazawa KI (1992) Adaptation of test shape for burrowing and locomotion in Spatangoid echinoids. Palaeontology 35:733-750

Knox GA (1994) Benthic communities. In: Knox GA (ed) The biology of the Southern Ocean. Cambridge University Press, Cambridge, p 193-220

Koehler R (1926) Echinodermata, Echinoidea. Australasian Antarctic Expedition 1911-1914. Sci Rep Ser C 3(3):1-134

Lockhart S, O'Loughlin PM, Tutera P (1994) Brood protection and diversity in echinoids from Prydz Bay, Antarctica. In: David B, Guille A, Feral JP, Roux M (eds) Echinoderms

Editorial responsibility: Otto Kinne (Editor-in-Chief), Oldendorf/Luhe, Germany through time. Balkema, Rotterdam, p 947-956

Mortensen T (1927) Handbook of the echinoderms of the British Isles. Humphrey Milford, Oxford University Press, London

Nichols D (1959) Changes in the chalk heart-urchin Micraster interpreted in relation to living forms. Phil Trans R Soc Ser B 242(693):347-437

Osinga R, Lewis WE, Wopereis JLM, Vriezen C, van Duyl FC (1995) Effects of a sea urchin Echinocardium cordatum on oxygen uptake and sulfate reduction in experimental benthic systems under increasing organic loading. Ophelia 41:221-236

Poulin E, Palma AT, Feral JP (2002) Evolutionary versus ecological success in Antarctic benthic invertebrates. Trends Ecol Evol 17(5):218-222

Sandnes J, Forbes T, Hansen R, Sandnes B (2000) Influence of particle type and faunal activity on mixing of di (2-ethylhexyl)phthalate (DEHP) in natural sediments. Mar Ecol Prog Ser 197:151-167

Schinner GO (1993) Burrowing behaviour, substratum preference and distribution of Schizaster canaliferus (Echinoidea: Spatangoida) in the Northern Adriatic Sea. PSZN I: Mar Ecol 14:129-145

Smith AB (1980) The structure and arrangement of echinoid tubercles. Phil Trans R Soc Ser B 289:1-54

Snedecor GW, Cochran WG (1989) Statistical methods. Iowa State University Press, Ames, IA

Stark JS (2001) Human impacts and assemblages in marine soft-sediments at Casey Station, Antarctica. PhD thesis, University of New England

Taylor F, McMinn A (2001) Evidence from diatoms for Holocene climate fluctuation along the East Antarctic margin. Holocene 11:455-466

Underwood AJ, Chapman MG (1998) GMAV5 for Windows. Institute of Marine Ecology, University of Sydney

Widdicombe S, Austen MC (1998) Experimental evidence for the role of Brissopsis lyrifera (Forbes, 1841) as a critical species in the maintenance of benthic diversity and the modification of sediment chemistry. J Exp Mar Biol Ecol 228(2):241-255

Widdicombe S, Austen MC, Kendall MA, Warwick RM, Jones MB (2000) Bioturbation as a mechanism for setting and maintaining levels of diversity in subtidal macrobenthic communities. Hydrobiologia 440:369-377

Yingst JY, Rhoads DC (1980) The role of bioturbation in the enhancement of bacterial growth rates in marine sediments. In: Tenor KR, Coull BC (eds) Marine benthic dynamics. University of South Carolina, Columbia, SC, p 407-421

Submitted: January 9, 2004; Accepted: November 4, 2004 Proofs received from author(s): March 15, 2005 